\title{
Clinical features, histopathological analysis and surgical treatment of a free floating vitreous cyst: a case report
}

\author{
Achados clínicos, análise histopatológica e tratamento cirúrgico de cistolivre no vítreo \\ posterior: relatodecaso
}

\author{
Rodrigo Pessoa Cavalcanti Lira ${ }^{1}$ \\ Patrícia Jungmann ${ }^{2}$ \\ Luis Felipe Lynch de Moraes ${ }^{3}$ \\ Ana Paula Teles Silveira ${ }^{4}$
}

\begin{tabular}{l} 
ABSTRACT \\
\hline The authors present a report of a 44 -year-old female patient, with com- \\
plaints of visual disturbances in the left eye. The symptoms were present \\
for at least 5 years and worsened in the last 2 years, impairing her activities. \\
The patient reported perception of a floating circle, which blurred her \\
vision. There was no previous history of trauma, infectious or inflammatory \\
disease. Clinical evaluation included physical examination, laboratory \\
testing, abdominal ultrasonography, thorax X-ray and head tomography. \\
Ophthalmologic examination consisted of visual acuity, motility tests, \\
biomicroscopy, tonometry and indirect ophthalmoscopy. Complementary \\
investigation was done with $\alpha$ and $\beta$ scan ocular ultrasonography. The \\
chosen therapeutic approach to excise the cyst was pars plana vitrectomy, \\
successfully performed. Anatomopathologic analysis revealed a pigmented \\
vitreous cyst, of possible congenital origin, described as a cystic choristoma \\
from the primitive hyaloid system. Benign evolution, clinical findings and \\
histopathological analysis corroborated the diagnostic hypothesis of a \\
cystic choristoma of the primitive hyaloid system. Surgery (pars plana \\
vitrectomy) was successful and the patient returned with visual acuity of \\
20/20 in both eyes, and with no further complaints.
\end{tabular}

Keywords: Vitreous body; Choristoma; Vitrectomy

\section{INTRODUCTION}

Idiopathic floating vitreous cysts giving rise to intermittent blurring of vision and visual field defects are a rare condition ${ }^{(1-10)}$. There were only few reports documenting clinical and histopathological features of such cysts and this is the first reported case in Brazil. This paper describes the ophthalmologic assessment, histopathologic findings and treatment results of a floating cyst from the vitreous of a 44-year-old patient, who came to the "Hospital das Clínicas", Universidade Federal de Pernambuco, Brazil.

\section{CASE REPORT}

M.L.R.S.F., a 44-year-old female patient came to our institution complaining of a mobile shadow (floater) in the central visual field of her left eye. The symptoms were present for 5 years, and had worsened in the past 2 , impairing her routine activities. She also noticed an increasing mobility of the floater, causing intermittent decrease in her visual acuity. She had no previous history of trauma, inflammatory or infectious ocular disease. 
Ophthalmologic examination disclosed best-corrected visual acuity of 20/20 in the right eye and 20/25 in the left eye. Ocular mobility was normal. Anterior segment biomicroscopy showed no signs of inflammation or disturbances in media transparency, the anterior chambers and iris were normal in both eyes, pupils were isochoric and photoreactive, intraocular pressure was $14 \mathrm{mmHg}$. The lens was transparent and in normal position in both eyes.

Fundoscopy was normal in the right eye, but revealed in the left eye an incomplete posterior vitreous detachment and a floating posterior vitreous cyst with limited mobility and positioned at the hialoid channel, with no contact with other intraocular structures. The cyst was translucent and had a smooth surface, which was covered with a brown pigment (Figures 1 and 2).

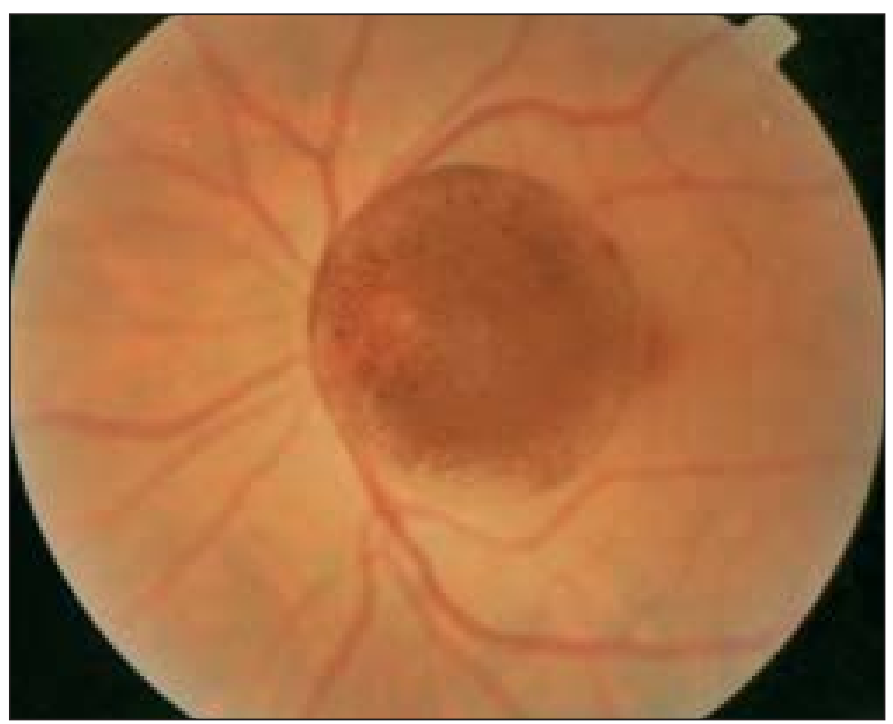

Figure 1 - Fundus photograph showing the free-floating vitreous cyst

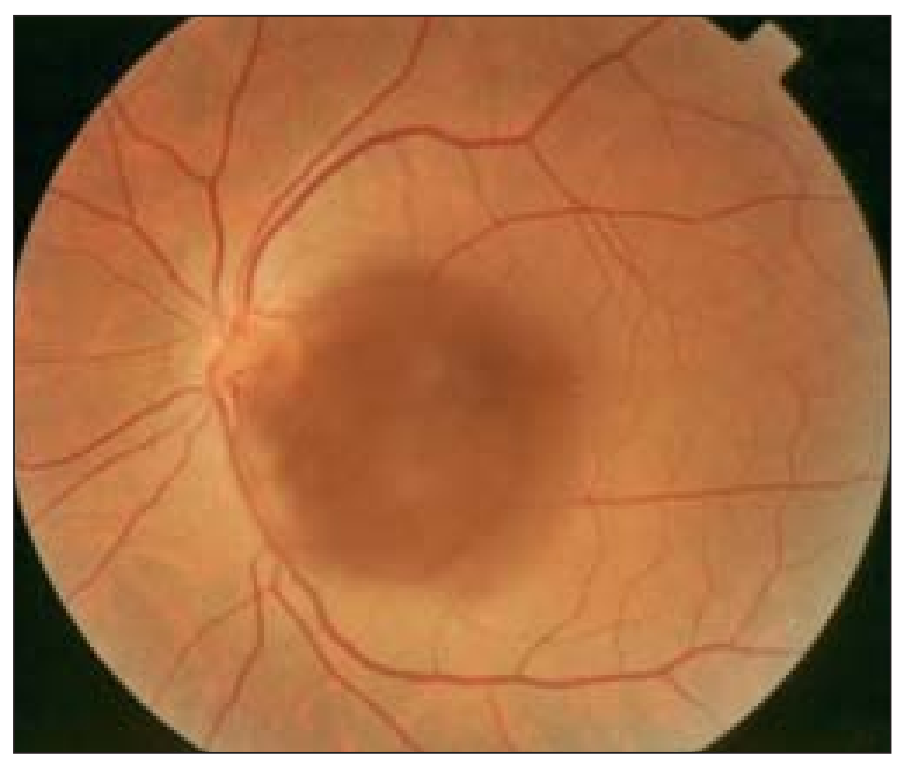

Figure 2 - Fundus photograph showing the vitreous cyst. Pigment clumping is seen
$\alpha$-Scan ultrasonography showed two peaks of medium to high reflectivity in the posterior vitreous and $\beta$-scan ultrasonography confirmed the presence of a hiperechogenic, spherical cyst with a $3-\mathrm{mm}$ in diameter. The cyst was situated at the center of vitreous cavity and had no attachment to other ocular structures.

The patient had a good general health and no noticeable illness. Clinical assessment included physical examination, blood testing with normal results (hemogram, sorology for Toxoplasma gondii and Toxocara sp., serologic tests for echinococcosis and cysticercosis, and complete blood cell count for eosinophilia). Abdominal ultrasonography, thorax $\mathrm{X}$-ray and brain tomography revealed no pathologic aspects.

During one year, the cyst was observed, presenting no change in aspect or symptoms. Therefore, the patient was given treatment options of laser photodisruption or vitrectomy to excise the cyst and she opted for vitrectomy.

Pars plana vitrectomy for cyst removal was successful. Histopatological material was sent for analysis. The patient signed authorization to study and publish case results.

The studied tissue showed a predominant monolayered cell pattern architecture, together with areas of transition to discontinuous stratification sectors from two to four cell layers. Those cells had cuboidal morphology (epithelial-type, without atypias). At higher magnification, the granular, rude nature of the brown, intracytoplasmic pigment was noticed in the cells of the cystic wall (Figure 3 ). There was no parasitic structure (specifically cysticercus) neither inflammatory or neoplastic cells, in the examined microscopic slides.

\section{DISCUSSION}

The first description of a free-floating vitreous cyst was presented in $1899^{(1)}$. Thereafter, during the twentieth century,

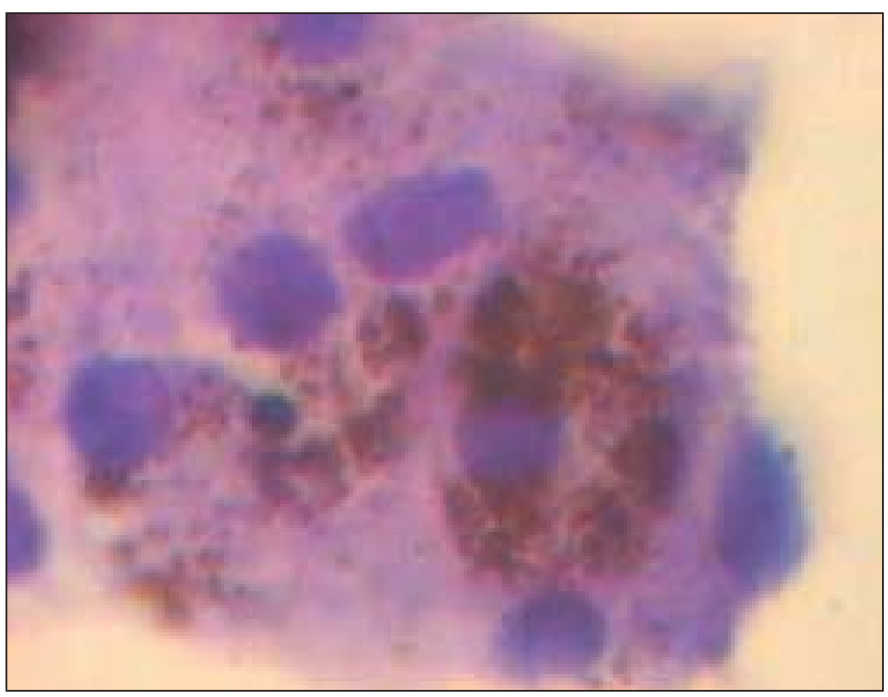

Figure 3 - On light microscopy, high-power view, the collapsed cyst wall shows to consist of pigmented epithelial cells (hematoxylineosin, X1000) 
approximately 50 cases were reported ${ }^{(2-10)}$. That shows how rare this condition may be. Thus, data regarding epidemiological aspects are insufficient. Cruciani et al. reviewed the literature on morphologic and clinical correlations, finding patients aged between 5 and 68 years, mostly between 10-20 years. Number of cysts and position include: single monolateral, single bilateral and multiple monolateral. Dimensions range from $0.15 \mathrm{~mm}$ to $12 \mathrm{~mm}$. Shape has been described as spherical, oval, lobulated, while the surface may be smooth or crenated. Cysts may have yellow-grey (non-pigmented) or brown (pigmented) color $^{(2)}$.

Considering cell pigment, the literature discusses the following possible histogenesis of congenital cyst formation: 1- reminescent hialoid channel; 2- retinal pigmented epithelium or; 3- ciliary body. The characteristics found in the present case are coincident with those described by Jones, leading to the diagnosis of cystic choristoma from the primitive hyaloid system ${ }^{(3)}$.

There has been controversy about the origin of vitreous cysts. After some inconclusive reports using light microscopy, Orellana et al. carried out in 1985 the first analysis of a vitreous cyst using electron microscopy. Their findings of predominantly large mature melanosomes associated with scattered immature ones (premelanossomes) led them to the hypothesis that the cyst was due to trauma and originated from the pigment epithelium ${ }^{(4)}$. More recently (1998), Nork et al. examined the histopathology of a congenital vitreous cyst, finding pigment epithelial-type tissue, having immature melanosomes (not seen after birth in normal pigment epithelium), Mittendorf's dot, position at the Cloquet's canal, which argue in favor of the hypothesis of a choristoma of the primary hialoidal system ${ }^{(5)}$.

Therapeutic approach to vitreous cysts depends on patients' desire, symptoms, amount of visual impairment, cysts characteristics and location. Most cysts in the vitreal cavity may be observed and followed up without any intervention. If significant symptoms appear, treatment is necessary. There are two procedures described in literature: laser disruption and vitrectomy via pars plana with cyst excision. A third option was to associate laser disruption with vitrectomy, specially in pigmented cysts ${ }^{(5-7)}$.

Argon or Nd:YAG laser photocystotomy may not be successful in cysts that are a part of the primary hyaloidal system because the residual tissue may remain tethered to the central vitreous and the patient may continue to be symptomatic.

Benign evolution, clinical findings and histopathological analysis corroborate the diagnostic hypothesis of a cystic choristoma from the primitive hyaloid system. Surgery (pars plana vitrectomy) was successful and the patient returned with visual acuity of 20/20 in both eyes, and with no further complaints.

\section{RESUMO}

Os autores apresentam relato de um caso de paciente de 44 anos, com história de dificuldade visual no olho esquerdo há 5 anos. A paciente referia a sensação de um círculo flutuando em sua visão. Os sintomas pioraram nos últimos dois anos, prejudicando suas atividades. Não havia história pessoal prévia de trauma ou de doença ocular inflamatória ou infecciosa. A avaliação clínica incluiu o exame físico, exames de laboratório, ultrasonografia abdominal, radiografia de tórax e tomografia de crânio e o exame oftalmológico consistiu em medida de acuidade visual, testes de mobilidade, biomicroscopia, tonometria e oftalmoscopia indireta. Investigação complementar foi realizada com ultra-sonografia ocular (modo A e B). A terapêutica escolhida para exérese do cisto foi a vitrectomia via pars plana, que transcorreu sem complicações. A análise anatomopatológica revelou cisto do vítreo, pigmentado, de presumível etiologia congênita, compatível com coristoma cístico do sistema hialóide primitivo. A evolução benigna, os achados clínicos e a análise anatomopatológica reafirmam a hipótese diagnóstica de coristoma cístico do sistema hialóide primitivo. A intervenção cirúrgica (vitrectomia pars plana) obteve sucesso no tratamento da paciente, que retornou apresentando acuidade visual de 20/20 em ambos os olhos, sem outras queixas.

\section{Descritores: Corpo vítreo; Coristoma; Vitrectomia}

\section{REFERENCES}

1. Tansley JO. Cyst of the vitreous. Trans Am Ophthamol Soc. 1899;8:507-9.

2. Cruciani F, Santino G, Salandri AG. Monolateral idiopathic cyst of the vitreous. Acta Ophthalmol Scand. 1999;77(5):601-3. Review.

3. Jones WL. Free-floating vitreous cyst. Optom Vis Sci. 1998;75(3):171-3.

4. Orellana J, O'Malley RE, McPherson AR, Font RL. Pigmented free-floating vitreous cysts in two young adults. Electron microscopic observations. Ophthalmology. 1985;92(2):297-302.

5. Nork TM, Millecchia LL. Treatment and histopathology of a congenital vitreous cyst. Ophthalmology. 1998;105(5):825-30.

6. Awan KJ. Biomicroscopy and argon laser photocystotomy of free-floating vitreous cysts. Ophthalmology. 1985;92(12):1710-1.

7. Ruby AJ, Jampol LM. Nd: YAG treatment of a posterior vitreous cyst. Am J Ophthalmol. 1990;110(4):428-9.

8. Asiyo-Vogel MN, el-Hifnawi el-S, Laqua H. Ultrastructural features of a solitary vitreous cyst. Retina. 1996;16(3):250-4.

9. Hasegawa N, Kimura T, Mizota A, Sano N, Adachi-Usami E. Floating vitreous cyst. Retina. 1996;16(6):540-2.

10. Steinmetz RL, Straatsma BR, Rubin ML. Posterior vitreous cyst. Am J Ophthalmol. 1990;109(3):295-7. 